\title{
THE ECOWAS COURT AS A HUMAN RIGHTS PROMOTER? ASSESSING FIVE YEARS' IMPACT OF THE KORAOU SLAVERY JUDGMENT
}

\author{
Horace S. AdJOLOHOUN*
}

\begin{abstract}
The 2005 reform initiated by the Economic Community of West African States (ECOWAS) had the double effect of putting an end to ten years of judicial lethargy and positioning its Community Court of Justice (ECCJ) as a promising international human rights body. One of the most illustrative cases of the Court's impact is the landmark Koraou (Slavery) judgment in which the ECCJ condemned Niger for failing to protect the complainant from enslavement by a third party. Five years after the Koraou decision, this paper uses empirical based theories, case study and factual evidence to interrogate whether the ECCJ's judgment has had any further effect than just restoring the dignity of an individual litigant. Such assessment is important to thousands of other human beings who still live in bondage in the rest of the region. Ultimately, the paper seeks to demonstrate that although it has not reached the irradiating model of the European Court of Human Rights, the ECCJ has the potential of becoming a human rights promoter in the region and beyond.
\end{abstract}

\section{INTRODUCTION}

In 2004, when the ECOWAS ${ }^{1}$ Community Court of Justice (ECCJ) heard its first ever individual case, Afolabi $v$ Nigeria,${ }^{2}$ many were sceptical about its success as a human

* BA, Licence (Université d'Abomey-Calavi \& Usam, Benin), LLM (Pretoria), Doctoral Candidate, Centre for Human Rights, University of Pretoria, South Africa. sathorace@yahoo.fr. I would like to thank Professor Erika de Wet, Professor Frans Viljoen and Dr Magnus Killander for their invaluable comments on earlier drafts of this article. All shortcomings remain my own.

1 The Economic Community of West African States (ECOWAS) was created in 1975 by a treaty signed between 15 States of the region with the initial aim of realising collective self-sufficiency through economic integration. See Treaty of the Economic Community of West African States (adopted 28 May 1975). In 1993, ECOWAS adopted a Revised Treaty. See Revised Treaty of the Economic Community of West African States (ECOWAS) (adopted 24 July 1993, entered into force 23 August 1995) REFWORLD Vol 2372 I-42835.

2 See Olajide Afolabi v Nigeria (2004) ECW/CCJ/JUD/01/04 in which the Court threw out the case for lack of jurisdiction as the 1991 Court Protocol allowed the Community Court to entertain 
rights protector in West Africa let alone a human rights promoter in the rest of the continent. In fact, the Court had existed on paper for more than a decade, ${ }^{3}$ its first bench of judges had waited idle for three years, ${ }^{4}$ and it could not entertain individual human rights complaints other than through Member States. The 2005 Supplementary Court Protocol ${ }^{5}$ literally brought the regional tribunal from the shadows of hypothetical inter-states human rights litigation into the light of promising international human rights adjudication. Articles 9 and 10 of the Protocol empowered the Court to hear individual human rights cases. The same year it received such powers, the ECCJ set the scene in Ugokwe $v$ Nigeria $^{6}$ by anchoring its material jurisdiction in the African Charter on Human and Peoples' Rights (African Charter), which the Community had chosen as its compass for realising regional integration. ${ }^{7}$

As a fully-fledged human rights body, the ECCJ raised much hope in the region and was eulogised in evocative terms. ${ }^{8}$ In fact, the Court came as a directly accessible judicial forum in an African human rights system with a long operating quasi-judicial African Commission ${ }^{9}$ and an access-limited nascent African

individual complaints only through the States of which the complainants are nationals.

3 Initially envisaged as the Tribunal of the Community under the 1975 Treaty, the Court, in its current form, was created by Protocol A/P1/7/91 Relating to the ECOWAS Community Court of Justice (adopted 6 July 1991, entered into force 5 November 1996).

4 See ST Ebobrah, 'A Critical Analysis of the Human Rights Mandate of the ECOWAS Community Court of Justice' Research Paper for the Danish Institute for Human Rights (on file with author) (2008) 16 and JA Hessbruegge, 'ECOWAS Court Judgment in Habré v. Senegal Complicates Prosecution in the Name of Africa' (2010) 15 Insights 2.

5 Supplementary Protocol A/SP.1/01/05 Amending Protocol A/P1/7/91 Relating to the ECOWAS Community Court of Justice (adopted and provisionally entered into force 19 January 2005).

6 See Hon. Dr. Jerry Ugokwe v Nigeria (2005) ECW/CCJ/APP/02/05 para 29. In the case, the Court decided that it has no jurisdiction to entertain the complainant's principal claim relating to domestic electoral matters. However, the Court held that 'by article 4(g) of the ECOWAS Revised Treaty, Member States are enjoined to adhere to the principles including (...) human rights in accordance with the provisions of the African Charter'. Such inclusion in the view of the Court 'behoves on it to bring in the application of those rights catalogued in the African Charter'.

7 While it had very few human rights issues on its agenda under the 1975 founding Treaty, ECOWAS embarked on a substantive treaty reform in 1991 following which the Community erected the African Charter as the main human rights instruments to guide its action towards the realization of socio-economic development. In the words of the Community, such a move 'arose from the need to adapt to the changes on the international scene'. See ECOWAS Revised Treaty (1993), art 4(g).

$8 \quad$ See for instance ST Ebobrah, 'A rights-protection goldmine or a waiting volcanic eruption? Competence of, and access to, the human rights jurisdiction of the ECOWAS Community Court of Justice' (2007) 2 African Human Rights Law Journal 328.

9 Created under the African Charter in 1981, the African Commission on Human and Peoples' Rights operated from 1987. Its main problems have been its subordination to the African Union, its lack of express powers to make binding decisions and poor state compliance with its recommendations. On these issues see F Viljoen, International Human Rights Law in Africa (Oxford $2^{\text {nd }}$ edn 2012) 339-343; R Murray, The African Commission on Human and Peoples' Rights and International Law (Oxford 2000) 54-55; F Viljoen and L Louw, 'State Compliance with the Recommendations of the African Commission on Human and Peoples' Rights' The American Society of International Law (ed) reprinted from (2007) 1 American Journal of International Law; GM Wachira and A Ayinla, 
Court. ${ }^{10}$ Actually, the West African Court represents an alternative, if not a competitor, to its two senior continental counterparts, at least for West African litigants. First, the three bodies share the African Charter as the basis for their material jurisdiction. Second, the ECCJ's personal jurisdiction extends to 15 ECOWAS Member States which also adhere to the African Commission and African Court's regime. Finally, as opposed to the two other bodies, the sub-regional Court does not demand that local remedies be exhausted prior to receiving a case. Endowed with such advantages the ECCJ did not belie the promises vested in it. Since the rise of individual complaints due to the 2005 reform, the Court has received more than 140 cases $^{11}$ and delivered 59 judgments $^{12}$ of which at least 44 were in respect of human rights. Proceedings before the Court have involved a variety of litigants ranging from common ECOWAS citizens to former heads of states. ${ }^{13}$

Depending on the case, the Court ordered states to pay monetary compensation or take other actions for violating African Charter rights. Remedies granted have ranged from US\$200,000 compensation for tortured Gambian journalist Ebrimah Manneh, ${ }^{14}$ to a declaration, in the Socio-Economic Rights and Accountability Project (SERAP) Education case, ${ }^{15}$ that socio-economic rights are justiciable in Nigeria. In 2011, the ECCJ was not shy to declare the enactment of blanket amnesty laws in Niger in violation of effective remedies by referring to international criminal law in the Ibrahim case. ${ }^{16}$ Finally, a ground-breaking judgment of the ECCJ is the December 2012 decision in the SERAP Environment case in which the Court ordered Nigeria to 'ensure restoration of the environment of the Niger Delta, prevent the occurrence of

'Twenty Years of Elusive Enforcement of the Recommendations of the African Commission on Human and Peoples' Rights: A Possible Remedy' (2006) 6 AHRLJ 471.

10 Established in 1998, the African Court on Human and Peoples' Rights had its first bench of judges appointed in 2004 and heard its first case in 2009. Under its Protocol, the Court may receive cases from individuals and non-governmental organisations only after the state against which the case is brought has filed a declaration allowing such complaints. See Protocol to the African Charter on Human and Peoples' Rights establishing an African Court on Human and Peoples' Rights (adopted 10 June 1998, entered into force 25 January 2004) art 34(6). As of July 2013 seven of the 54 African Union Member States had made the declaration and the Court had received and decided a handful of cases.

11 As of June 2013 according to statistics obtained at the Court Registry.

12 Ibid.

13 Both former presidents Mamadou Tandja of Niger and Laurent Gbagbo of Côte d'Ivoire resorted to the Court to protect their rights after the former was toppled by a military coup and the latter was removed by a coalition of domestic and international forces. In Mamadou Tandja $v$ Niger (2010) ECW/CCJ/JUD/05/10, the Court ordered the military junta in Niger to immediately release former president Tandja. In Ivorian Foundation for the Observation and Monitoring of Human Rights and Political Life FIDHOP and 2 Others (Laurent Gbagbo) v ECOWAS Authority of Heads of State and Government Preliminary ruling on provisional measures (2011) ECW/CCJ/ADD/01/11, the Court ordered Member States and organs of the Community to refrain from intervening militarily in Côte d'Ivoire until it delivered its judgment on the merits.

14 See Chief Ebrimah Manneh $v$ Gambia (2008) ECW/CCJ/JUD/03/08.

15 See The Registered Trustees of the Socio-Economic Rights and Accountability Project (SERAP) $v$ Nigeria Preliminary ruling (2010) ECW/CCJ/JUD/07/10.

16 See Sidi Amar Ibrahim and Another v Niger (2011) ECW/CCJ/JUD/02/11. 
damage to the environment, and hold the perpetrators of the damage accountable'. ${ }^{17}$ A close examination shows that the Court is developing a growing jurisprudence and tackling some of the key human rights issues under the African Charter. The focus is placed on procedural matters such as the reinforcement of the exemption from exhausting local remedies. The Court has also adjudicated substantive issues like the justiciability of socio-economic rights in a region plagued with poverty and slavery, which is still current in many West African countries.

Particularly for its findings in the SERAP Education case, the Community Court was commended by local and international civil society, ${ }^{18}$ scholars, ${ }^{19}$ and the media alike. ${ }^{20}$ However, the celebrated Koraou Slavery case has indisputably remained so far the most acclaimed judgment of the ECCJ as a regional human rights court. In the case of Hadijatou Mani Koraou v Niger ${ }^{21}$ decided in 2008, the Community Court condemned Niger for failing to protect Koraou from slavery in which her master forced her to live for a decade between 1996 and 2005. Amid huge publicity for both the Court and the victim, commentators suggested that 'the African judge has made history'. ${ }^{22}$ Indeed, the case was one of the very few in which an international court found a positive obligation for states to protect their nationals from slavery. ${ }^{23}$ The Koraou judgment equally attracted huge international pressure to Niger and positioned the ECCJ as a

17 SERAP (Environment) v Nigeria Judgment ECW/CCJ/JUD/18/12 of 14 December 2012.

18 See Right to Education Project, 'Landmark Court Decision on Right to Education' (2010), <www. right-to-education.org/node/719> accessed 14 February 2011, SERAP, 'ECOWAS Court to Federal Government: Nigerians Have the Right to Education' <www.serap-nigeria.org/cover/ecowascourt-to-fg-nigerians-have-a-legal-right-to-education/> accessed 14 February 2011; and Amnesty International, 'ECOWAS Affirms Nigeria Accountable for Ensuring the Right to Education' (2010) <www.amnesty.org/en/library/asset/AFR44/032/ 2010/en/603056fb-d3f4-473f-acbf-f416beb402e0/ afr440322010en.html> accessed 14 February 2011.

19 See for instance ST Ebobrah, 'Human Rights Developments in African Sub-regional Economic Communities During 2009' (2010) 1 AHRLJ 251; ST Ebobrah 'Human Rights Developments in SubRegional Economic Communities during 2011' (2012) 12 AHRLJ 223.

20 See EKOAKETE News, 'ECOWAS Court Orders Nigeria to Provide Free and Compulsory Education' (2010) <http://ekoakete.com/2010/12/01/ecowas-court-orders-nigeria-to-provide-freeand-compulsory-education/> accessed 14 February 2011; AllAfricaCom, 'Nigerians Have Legal Right to Education, ECOWAS Court Rules' <http://allafrica.com/stories/ 200911230024.html> accessed 14 February 2011.

21 See Dame Hadijatou Mani Koraou v Niger (2008) ECW/CCJ/JUD/06/08.

22 D d'Allivy Kelly, 'Le juge africain est entré dans l'histoire: Cour de justice de la CEDEAO, 27 octobre 2008, Hadijatou Mani Koraou c/ Niger' in Le Monde 'Combat pour les droits de l'homme' (10 May 2009) <http://combatsdroitshomme.blog.lemonde.fr/2009/05/10/le-juge-africain-est-entre-danslhistoire-cour-de-justice-de-la-cedeao-par-delphine-dallivy-kelly/> accessed 5 July 2012; G Badet 'Un nouveau pas franchi dans la mise en œuvre de la responsabilité des Etats membres de la CEDEAO pour violation des droits de l'homme commise sur leur territoire par des particuliers: commentaire de l'arrêt Koraou c. Niger' (2010) 23 Revue Béninoise de Sciences Juridiques et Administratives 154-194.

23 A similar case is Siliadin v France App no 73316/01 (ECtHR, 26 July 2005) in which the European Court of Human Rights found that France had the positive obligation under article 4 of the European Convention on Human Rights to protect Togolese national Siwa-Akofa Siliadin from slavery, servitude and forced labour suffered at the hands of a French couple with the help of whom she arrived in France in 1994. 
human rights haven. Moreover, Koraou won the first ever monetary award ${ }^{24}$ granted by the ECCJ together with political recognition abroad ${ }^{25}$ and social acknowledgment at home. ${ }^{26}$ Finally, the Koraou decision is one of the ECCJ's judgments that attracted the fastest state compliance. ${ }^{27}$

The ECCJ may also be celebrated for attracting state compliance. Of its nine human rights judgments on the merits, six have seen full or situational compliance, which identifies cases in which compliance occurred after a change of government following a coup d'Etat or a regime change. It may be premature to demand compliance in two of the three situations of non-compliance. ${ }^{28}$ Despite these achievements, the ECCJ still has a long way to go if it is to assert itself as an authoritative international human rights court. Decisions of international bodies seek, and in fact have, wider effects than just satisfying particular claims brought in specific applications. ${ }^{29}$ Put in context, the role of a regional court is to use individual cases to speak to regional situations such as socio-economic underdevelopment and slavery that are prevalent

$24 \quad$ The Court ordered Niger to pay CFA 10 million (approximately $\$ 20,000$ ) to the victim.

25 See Interights, 'Hadijatou Mani (Koraou) v Niger' <www.interights.org/niger-slavery/index.html> accessed 5 July 2012. The London based NGO Interights reports that 'Hadijatou has been honoured for her courage in various contexts, including being awarded the US State Department's 'International Woman of Courage Award 2009', presented by US Secretary of State Hillary Clinton. As a result of the case, Hadijatou was named in Time Magazine as one of the top 100 most influential people in 2009'.

26 As a result of the ECOWAS Court judgment, Koraou gained social recognition in her community and at country level. The former slave currently lives back in her village in Niger where she established a home, bought a few animals to become economically self-sufficient and arranged a savings plan for the future. See H Duffy, 'Implementation of an ECOWAS Court Judgment: Hadijatou Mani Koraou v The Republic of Niger' (2010) 6 Interights Bulletin 66.

27 The ECCJ's judgment was delivered on 27 October 2008 and payment of the monetary compensation occurred on 17 March 2009. The payment process unfolded as follows: 1) In early December 2008, Counsel for Koraou notified the ECCJ's judgment to the Secretary General of the Government who transmitted it to the Director of the Contentieux d'Etat (Directorate of State Litigation); 2) On 12 December 2008, the Director sent a Lettre de mandatement to the Finance Minister requesting that the National Treasury pay within three weeks; 3) After the Finance Minister issued the mandat and bon d'engagement on 17 March 2009, a check was deposed and paid on the same date to Koraou's counsel; payment occurred towards the end of the financial year while implementation of state budget was almost completed; the counsel wrote a check to Koraou on 21 March 2009. See interviews with Mr Abdou Hamani, Magistrate, Director of State Litigation between 2007-2010 (Niamey, 16 May 2011); Advocate Abdourahaman Chaibou, Counsel for Koraou (Niamey, 18 May 2011). The fastest compliance was by Togo, which paid compensation within 25 days of the judgment in Ameganvi Isabelle Manavi v Togo (Parliamentarians case) (2011) Judgment ECW/CCJ/JUD/09/11. In the Manneh case, the Court decided in its final judgment of 6 February 2012 that it could not grant compensation until seven years have passed since the disappearance of the victim thus upholding Gambia's argument (however, the $\$ 100,000$ initial compensation ordered by the Court has not been paid yet); in the case of Musa Saidykhan $v$ Gambia (2010) ECW/CCJ/JUD/08/10 (illegal arrest of a journalist), the review judgment of 6 February 2012 dismissed the application for lack of merits.

29 See RA Atuguba, 'Public Interest Litigation: A Critical Ingredient for Effective Human Rights Activism in Africa' (2009) 1 Journal of the West Africa Public Interest Litigation Centre 7-12; B Mason Meier et al, 'Bridging International Law and Rights-based Litigation: Mapping Healthrelated Rights through the Development of the Global Health and Human Rights Database' (2012) 14 Health and Human Rights 3-4. 
in ECOWAS countries. The ECCJ slavery judgment ended Koraou's plight, but what of the other thousands of human beings still enslaved in Niger, Mali and Mauritania? Considering that domestic courts, and in fact other state organs, are naturally better situated to deal with individual claims, an international court like the ECCJ would be a wasted opportunity if it could not yield a wider impact. The Koraou judgment provided the Court with such an opportunity.

There is, therefore, a need to assess whether and how such a role has been achieved five years after the Koraou decision. This paper endeavours to investigate the actual or potential presence of some impact situations as prompted by the Koraou judgment. The next section sets out some theories on impact combined with illustrations borrowed from empirical works on regional regimes in Europe, the Americas and Africa. In line with this construction of impact, the following section investigates any effect, actual or potential, of the Koraou judgment on the domestic system of Niger. The impact analysis extends to reverse effects, if any, of Nigerien courts on the ECCJ's human rights jurisprudence. The discussion then proceeds to interrogate the presence of 'spill over' effects in other ECOWAS countries that were not a party to the Koraou case. The final section discusses the impact beyond ECOWAS.

\section{THEORETICAL AND EMPIRICAL APPROACH TO IMPACT}

This paper refers to 'impact' as the effect or influence of the jurisprudence of an international court or body on the domestic system of states, including the executive, judiciary and legislature. One-way influence is concerned with actions by domestic organs to adjust national policy, legislation or adjudication with the findings of the deciding body; ${ }^{30}$ or the body's jurisprudence prompting litigation on similar issues before domestic organs. Two-way influence applies to cases in which there is evidence of domestic practices or decisions enlightening or shaping arguments in the international decisions. Finally, 'spill over' influence is illustrated by situations where domestic systems show signs of a systemic effect of the international body's jurisprudence, which 'irradiates' to other Member States, systems and mechanisms within the same region and beyond.

Although domestic courts are the natural counterparts of international courts, the executive and legislature do not escape the influence of international adjudication as they all belong to a same addressee of international norms, the state. Studies have revealed that domestic and international courts do not operate in complete normative isolation from each other, but rather interact. ${ }^{31}$ Some have concluded that whether domestic or international, 'a court is not a closed place where judges decide cases in camera, but rather a cross-road, a circular juncture where court pronouncements

$30 \quad$ This could be either to facilitate compliance with the initial order or by taking preventive measures to avoid being called before the regional court on future occasions.

31 See Y Shany, Regulating the Jurisdictional Relations Between National and International Courts (Oxford 2007) 3. 
meet in an orderly manner to build a dynamic law'. ${ }^{32}$ Others have ascertained that the destination of international decisions is the domestic system, where organs of the state, including courts, are better equipped to give effect to the outcome of international adjudication. ${ }^{33}$ Illustration of these propositions can be found in USA ${ }^{34}$ and Israeli ${ }^{35}$ domestic courts regarding ICJ judgments.

While relations between international and domestic courts are evident, ${ }^{36}$ how they are shaped and create influence is central to the development of international law, especially to the success of regional - human rights - regimes. Influence may be inferred from statutory hierarchical relations, interaction, cooperation, and collaboration whether normative or jurisprudential. For instance, exhaustion of local remedies, complementarity, preliminary ruling mechanisms, and other electa una via rules are some of the inter-jurisdictional relations that have the potential of yielding influence. $^{37}$

Even in instances where potential relations are prevented or limited by the adoption of the rule of non-exhaustion of local remedies, domestic and international courts may still interact through subsidiarity or complementarity. ${ }^{38}$ Such interaction has been explained by the fact that despite the tremendous development of international adjudication, domestic courts remain a 'natural judge' of international law. In other words, the municipal system is 'home' to international law of which national courts are the primary enforcers. ${ }^{39}$ Worth noting, notwithstanding the adoption of the rule

32 G Canivet, 'Les influences croisées entre juridictions nationales et internationales' <www.ahjucaf. org/Les-influences-croisees-entre,7177.html> accessed 16 April 2012. Mr Canivet is former President of the French Court of Cassation and member of the Constitutional Court of France.

33 See L Garlicki, 'Cooperation of Courts: The Role of Supranational Jurisdictions in Europe' (2008) 6 (3 and 4) ICON 521.

34 See LaGrand Case (Germany v USA) (Merits) [2001] CJ Rep 466; Avena and Other Mexican Nationals Case (Mexico v United States of America) (Merits) [2004] ICJ Rep 12, 70.

35 See Legal Consequences of the Construction of a Wall in the Occupied Palestinian Territory Case (Advisory Opinion) [2004] ICJ Rep 136.

36 On such relations and influence, see generally VM Kamto, 'Les interactions des jurisprudences internationales et des jurisprudences nationales' in SFDI (ed) La juridictionnalisation du droit international (Pédone 2003) 393-460; VWA Schabas, 'L'influence de la Convention européenne des droits de l'homme sur la jurisprudence des Cours suprêmes des pays du Commonwealth' in J-F Flauss (dir.) L'influence de la Convention européenne des droits de l'homme sur les Etats tiers (Bruylant 2002) 29-53.

37 See in general Shany (n 31).

38 The principle of complementarity is now legally established in the Rome Statute and the practice of the International Criminal Court. See JL de la Cuesta and A Eser, 'Concurrent National and International Criminal Jurisdiction and the Principle "Ne bis in idem" (2001) 72 Revue internationale de droit comparé 753-764; A-M Slaughter, 'A Global Community of Courts' (2003) 44 Harvard International Law Journal 191.

39 See A Tzanakopoulos, 'Domestic Courts as the 'Natural Judge' of International Law: A Change in Physiognomy' Paper presented at the Workshop on the Use of International Law in Domestic Courts in West Africa, $19^{\text {th }}$ African Human Rights Moot Court Competition Cotonou - Benin (8 October 2010). The position of the author is supported by preliminary provisions of most international human rights conventions that place implementation obligations primarily on states. Cases also 
of non-exhaustion of local remedies, the large majority of ECOWAS Court cases decided between 2005 and 2012 were examined by domestic courts at some point before ending up in the Community Court. ${ }^{40}$

The influence of international courts may also depend on vertical or horizontal relations regulated by international law such as is the case for preliminary rulings. In the horizontal situation, the two sets of courts have concurrent material, personal and local jurisdiction. ${ }^{41}$ In the vertical situation, they are part of the same hierarchical system where international courts are positioned on top either through a compulsory referral mechanism or the authority of the 'supranational' findings. ${ }^{42}$ Similar relations are found in regional integration frameworks with the purpose of legal harmonisation..$^{43}$ In the particular framework of international human rights regimes, compliance means much more than just paying monetary compensation or releasing detainees. It ultimately implies drawing other implicit consequences of the decisions and undertaking necessary adjustments to bring domestic systems in line with regional norms. ${ }^{44}$ In some instances, consequences to be drawn are explicit, the order being much broader such as in the InterAmerican system. ${ }^{45}$

Where courts have no legal requirement to collaborate, scholars defending a socialisation approach to judicial cooperation have investigated the role of democracy and communitarianism in shaping the influence of international courts on their municipal counterparts. ${ }^{46}$ Yet, in those instances, influence is not envisaged without the authority and ability of the influencing court on the one hand and the openness of the receiving court to be influenced by the other. ${ }^{47}$ This may explain the argument

abound of domestic court decisions relying on international law or adjudication as available online under the International Law in Domestic Courts (ILDC) Project <www.oxfordlawreports.com/ subscriberarticlesbycategory? module=ildc $>$.

40 See in general Horace Adjolohoun 'Realising Human Rights through Regional Integration? State Compliance with the Judgments of the ECOWAS Court of Justice' draft article on file with author submitted for publication in Volume 52 of the Columbia Journal of Transnational Law (2013).

$41 \quad$ See Shany (n 31) 27-39.

42 In such instances, international courts play a 'transnational' or 'supranational' role vis-à-vis domestic courts. See Shany ibid 33-34; D Sloss, 'Treaty Enforcement in Domestic Courts: A Comparative Analysis' in D Sloss (ed) The Role of Domestic Courts in Treaty Enforcement: A Comparative Study (Cambridge 2009).

43 This is relevant to West Africa, not only for ECOWAS but also the West African Economic and Monetary Union (UEMOA) and the Organisation of the Harmonisation of Business Law in Africa (OHADA).

$44 \quad$ See Garlicki (n 33) 520.

45 See for instance A Huneeus, 'Courts Resisting Courts: Lessons from the Inter-American Court's Struggle to Enforce Human Rights’ 44 (2011) Cornell International Law Journal 493-533.

46 See for instance Shany (n 31) 99-104; and A-M Slaughter (n 38) 191.

47 See Canivet (n 32) 5; the author singles out some factors for jurisprudential influence, which include the authority of the issuing body, its notoriety, moral authority, force of conviction of arguments and the quality of the legal system. He argues that the best elaborated decisions will, therefore, attract greater influence, because they build on values of universal scope. Alter considers the persuasiveness of arguments as the dominant mode of diffusion. See KJ Alter, 'The Global Spread of European Style International Courts" (2012) 35(1) West European Politics 135-154. 
that both national ${ }^{48}$ and international ${ }^{49}$ prominent human rights bodies mostly refer to the European Court of Human Rights (ECHR) case law for example than to the African Commission's jurisprudence. ${ }^{50}$

There is equally evidence that relations between international and domestic courts are not only top-down but also bottom-up. ${ }^{51}$ Illustrations abound of the ECHR reverting to domestic jurisprudence to understand social and political realities while adjudicating cases close to their original context. ${ }^{52}$ Changes in domestic jurisprudence have also forced European judges to move the trajectory, ${ }^{53}$ or reduce states' margin of appreciation depending on greater or lesser consensus at the domestic level. ${ }^{54}$ As an interesting illustration of this, the ECHR did not hesitate to extensively quote the Polish Constitutional Court in resolving a case ${ }^{55}$ that had been examined by domestic courts. ${ }^{56}$ Similar influences have been demonstrated in the Inter-American Human Rights System. ${ }^{57}$

The influence phenomenon has expanded far beyond the inter-jurisdictional realm, irradiating all sections of the state, shaping the behaviour of the Executive and prompting legislative changes. Studies provide empirical indication that the Inter-American Court of Human Rights (IACHR) has contributed to shaping state behaviour by guiding legal

48 For instance, in years of adjudication the Benin and South African highest courts have cited very few to no African Commission decisions at all in their judgments. For Benin, see Horace Adjolohoun Droits de l'homme et justice constitutionnelle en Afrique: le modèle béninois à la lumière de la Charte africaine des droits de l'homme et des peuples (L'Harmattan 2011) 110-111. For South Africa, see President of the Republic of South Africa and Others v Modderklip (Pty) Ltd 2004 (6) SA 40 (SCA).

The ECOWAS Court of Justice has made very few references to the African Commission's decisions in its human rights judgments. Such references should rather be termed as simple mentions, as was the case in the Koraou judgment. Conversely, the ECCJ mostly relies on the ICJ and European Court of Human Rights decisions. See Viljoen (n 9) 451-456; ST Ebobrah, 'Human rights developments in African sub-regional economic communities during 2009' (2010) 1 AHRLJ 242-258.

50 Out of the African context, even courts in very conservative jurisdictions such as the USA have reversed long established precedents to embrace international law not ratified by the US by referring to controversial ECHR case law. In the same vein, ECHR case law has been widely cited in Australia, Canada, New Zealand and South Africa. See Canivet (n 32); and Schabas (n 36).

51 See Garlicki (n 33) 513; Canivet (n 32) 2-3; and Kamto (n 36).

52 See, for instance, Vo $v$ France App no 53924/00 19 (ECtHR, 8 July 2004), which dealt with the recognition of the foetus.

53 Such as in Cossey $v$ The United Kingdom App no 10843/84 (ECtHR, 27 September 1990) dealing with homosexual marriages.

54 See Mazurek v France App no 34406/97 (ECtHR, 1 February 2000), which dealt with children born out of wedlock; and Fretté v France App no 36515/97 (ECtHR, 26 February 2002), which dealt with parental rights and private and family life of homosexuals.

55 Hutten-Czapska v Poland App no 35014/97 (ECtHR, 19 June 2006) regarding property rights.

$56 \quad$ See Garlicki (n 33) 514.

57 See among others JL Cavallaro and SE Brewer, 'Reevaluating Regional Human Rights Litigation in the Twenty-First Century: The Case of the Inter-American Court' (2008) 102 American Journal of International Law 768-827; A Huneeus, 'Rejecting the Inter-American Court: Judicialisation, National Courts, and Regional Human Rights' in J Couso et al (eds) Cultures of Legality: Judicialisation and Political Activism in Latin America (Cambridge University Press 2010) 113-138. 
and political reforms. ${ }^{58}$ Furthermore, impact studies have established top-down and bottom-up approaches to the socialisation of European human rights law under the auspices of the ECHR. ${ }^{59}$ In the view of the author, the ECHR has impacted wider national systems and has been instrumental in socialising a 'pan European consensus' on some key issues. Specific outcomes of the European 'spill over' impact model are both wide and varied. ${ }^{60}$ Impact research demonstrated similar influence of the African ${ }^{61}$ and Inter-American ${ }^{62}$ human rights regimes on the domestic systems of member states.

\section{THE INFLUENCE OF THE KORAOU JUDGMENT ON NIGER'S DOMESTIC SYSTEM}

Despite its 'decentralisation', international law is said to suffer from a 'chronic illness' of under institutionalisation and under enforcement. ${ }^{63}$ Yet, the ECOWAS human rights regime was shaped differently. Judgments of its Court of Justice enjoy direct enforceability in the municipal sphere and, as indicated earlier, they have received a fairly acceptable level of compliance, including the Koraou judgment. The ECCJ is, therefore, presumed to generate influence on domestic systems through the binding nature of its judgments on all branches of the defendant state, executive, legislature and judiciary; their superiority and precedence over domestic courts' decisions, and their direct enforcement.

58 See for instance F Basch et al, 'The Effectiveness of the Inter-American System of Human Rights Protection: A Quantitative Approach to its Functioning and Compliance with its Decisions' (2010) 7 Sur - International Journal on Human Rights 9; Cavallaro and Brewer (n 57); and J Couso et al (n 57).

59 As a major study in this line see H Keller and A Stone Sweet (eds) A Europe of Rights: The Impact of the ECHR on National Legal Systems (Oxford 2008). See also Cavallaro and Brewer (n 57); and D Shelton 'The Boundaries of Human Rights Jurisdiction in Europe' (2003) 13 Duke Journal of Comparative and International Law 95-153.

60 These include the Austrian modified Code of Criminal Procedure; Belgium amended its penal code, law on vagrancy, and civil code; Germany modified its criminal code of procedure regarding pretrial detention, gave legal recognition to transsexuals and took action to accelerate criminal and civil proceedings; the Netherlands modified the code of military justice and law on detention of mental patients; Sweden introduced rules on expropriation and legislation on building permits; Switzerland amended its military penal code and completely reviewed its judicial organisation and criminal procedure applicable to the army; and France strengthened the protection of the privacy of telephone communication.

61 See for instance Centre for Human Rights, Celebrating the African Charter at 30: A Guide to the African Human Rights System (Pretoria University Law Press 2011) 60-61. The guide demonstrates that 'through its progressive interpretation of the [African] Charter, the [African] Commission has given guidance to states about the content of their obligations under the Charter, and its provisions have inspired domestic legislation'; on the other hand, 'national courts are increasingly influenced by and use the Charter and the Commission's findings to assist them in interpreting national law'. For an in-depth study of the impact of the African human rights system in 19 African states see in general Centre for Human Rights (ed) Implementation of the African Charter and Women Protocol in Selected African States (PULP 2012).

62 See Basch et al (n 58); Cavallaro and Brewer (n 57); and J Couso et al (n 57).

63 See Tzanakopoulos (n 39) 16. 
One may concur that there is room for an 'orientation effect [to be] inevitable', ${ }^{64}$ although this may not be concluded before ascertaining that ECCJ's judgments have prompted changes in the municipal sphere of defendant states, beyond the specific orders made in their operative parts. Both actual and potential changes are discussed only for instances where evidence existed of such influence or when the effect is demonstrated as unavoidable.

\subsection{HAS THE KORAOU JUDGMENT IMPACTED GOVERNMENT POLICY?}

Considering that Niger had criminalised slavery in its penal code before the Koraou case ${ }^{65}$ one could assume the judgment did not require any preventive or forward-looking action from the executive. This is because, in such a situation, the duty lies with domestic courts to just apply the law. However, despite the criminalisation of slavery from 2003, an estimated 43,000 people were believed to remain in slavery across Niger in $2010 .{ }^{66} \mathrm{By}$ 'promoting public debate on an issue sustained under the code of silence', ${ }^{67}$ the judgment, therefore, provided an opportunity for the Government of Niger to take measures to the effect that the law is better implemented. Above all, it was Niger's Government that was condemned for having failed to protect Koraou from violation by a third party.

Accordingly, one would have expected sensitisation and other public measures by the Government to ensure greater and more effective implementation of the law. The picture is rather mixed. Upon the proposal of the Directorate of Civil Litigation, the Ministry of Justice issued a circulaire to judges with express instruction to handle cases, and more specifically slavery related matters, with greater diligence. ${ }^{68}$ However, the circulaire has not been effectively enforced - if at all. In the same vein, police officers have not addressed long delays in investigating slavery matters. ${ }^{69}$ Investigating officers are believed to lack a good knowledge of the 2003 anti-slavery legislation, ${ }^{70}$ while an accurate characterisation of the facts is key to fighting slavery as a crime through law enforcement. The problem is that police or gendarmerie officers fail to properly characterise the facts of the case either by not properly applying the law or due to their cultural or religious bias. ${ }^{71}$ As a consequence, several constituted slavery cases are thrown out by the judges.

\footnotetext{
$64 \quad$ See LR Helfer and E Voeten, 'Measuring Judicial Influence: Does the European Court of Human Rights Promote Social and Legal Change?' Conference on 'Domestic Consequences of Human Rights Treaty Ratification' (15-16 October 2010) NYU School of Law’s Centre for Human Rights and Global Justice.

65 See Loi $N^{\circ} 2003-025$ du 13 juin 2003 modifiant la loi $N^{\circ}$ 61-27 du 15 juillet 1961, portant institution du Code Pénal, Journal Officiel spécial $N^{\circ} 4$ du 7 avril 2004.

66 See Duffy (n 26) 66.

67 Ibid.

68 Interview with Abdou Hamani (n 27).

69 Ibid.

70 Interview with Ibrahim Habibou, President of anti-slavery NGO Trimidria (Niamey, 18 May 2011).

71 Ibid.
} 
With regard to awareness and capacity buildings initiatives expected for a greater enforcement of the law, they were instead undertaken by non-governmental organisations. Civil society organisations also openly complained of the Government's failure to design and implement such initiatives as 'zero tolerance' programmes. Instead of the support that would have been expected, officials initially demonstrated little interest in campaign programmes initiated by international organisations. An illustration is provided by the reluctance of the Government to support a two-year pilot project initiated by the International Labour Organisation aiming to focus the attention of civil servants on tackling 'forced labour' in Niger. ${ }^{72}$ In fact, slavery was denied at the highest level of the state. In his time, former Nigerien President Mamadou Tandja was quoted to have, on various occasions, publicly denied that slavery still existed in Niger and even had anti-slavery activists arrested. ${ }^{73}$

The Government of Niger should have also initiated policy measures to ensure that all its branches discharge their duty to enforce anti-slavery provisions more effectively after the ECCJ's judgment. Importantly, prefects vested with administrative authority at the province level play an important role in law enforcement. In fact, the prefect of Konni, the town where Koraou lived, triggered Niger's responsibility in the case by failing to act upon Koraou's initial complaint. Niger's obligation to protect was thus established through the omission of a state official. There is no evidence that the Government has instructed prefects to the effect of drawing the full consequences from the ECCJ's judgment.

The same situation seems to apply to Niger's obligation to promote nondiscrimination and zero tolerance to slavery as a consequence of the ECCJ's judgment. Indeed, even if the ECCJ did not find discrimination on the basis of sex, it addressed the issue and found that factual elements existed that pertain to such discrimination. ${ }^{74}$ Accordingly, it should have appeared to the Nigerien Government that persisting slavery practices - despite legislative measures - demand a shift in the approach to implementation. In her submissions, the complainant has abundantly demonstrated that her dual situation of wife and slave was discriminatory as compared to other legitimate free wives of her master. In addition and by extension, the categorisation of people enslaved in Niger might include gender, ethnicity and others. Arguments made in the ECCJ's judgment and a poor implementation of the law should have drawn the Government's attention to the need to interrogate these considerations. The Government has not lived up to its obligation to promote the rights of women, especially in a country that has made several reservations to United Nations Convention on the Elimination of All Forms of Discrimination Against Women (CEDAW).

\footnotetext{
$72 \quad$ Ibid.

73 See interview with Ilguilas Weila, Former President of Nigerien anti-slavery NGO Timidria (Niamey, 16 May 2011). See also G Sanda, 'L’esclavage a évolué. Y a-t-il eu des progrès? Pas vraiment!' (2010) <www.cesep.be/ETUDES/ENJEUX/esclavage.pdf> accessed 26 April 2012.

$74 \quad$ See Badet (n 22) 158.
} 


\subsection{THE ECOWAS COURT AS A PROMOTER OF LEGISLATIVE REFORMS?}

As pointed out earlier, Niger already had anti-slavery provisions at the time the ECCJ condemned the state in the Koraou judgment. The law had entered into force and had even been used by courts, as will be illustrated later. Hence, the Koraou judgment had no legislative implications in Niger in terms of repealing existing laws or adopting a new one. Although legislative intervention was not needed, proceedings in the Community Court revealed the need for Niger to assess its anti-slavery law five years after the legislation was adopted. Against the background of enforcement problems, such assessment could include interrogating possible practical inadequacies or shortcomings, and the need for further regulations or implementing decrees to ensure effectiveness.

Practical issues facing an effective implementation of the 2003 law are discussed in the sections dealing with influence on the executive and domestic courts. In this section, it must simply be stressed that, as the main promoter of legislative reform at the domestic level, the Government of Niger has a duty to take further necessary actions to ensure that the law is fully implemented.

The failure of the Government to enforce its circulaire is illustrative of the lack of political will to enforce the anti-slavery provisions in the penal code to their fullest. In fact, one may wonder why a circulaire but not an implementing presidential decree, which, signed by the head of the executive, would have demonstrated greater commitment and willingness to seriously address the issue. A decree also carries greater legal weight and binding force than a circulaire, which is merely an administrative document issued at directorate level. It should not be ignored that the main stakeholders or primary addressees of any such acts are municipal judges, hence the question whether executive acts would violate the separation of powers. However, the boundaries between the separation of powers are blurred in the domestic system of many countries. Niger is not an exception. Prosecuting judges and authorities whose intervention is central to law implementation and enforcement are placed within the hierarchical authority of the minister of justice who is a sitting member of the Cabinet. These officials play an important role in law implementation and enforcement.

Niger's approach to the criminalisation of slavery is not exempt from criticism either. The 2003 amendment to the Nigerien Penal Code criminalises slavery as both a felony and misdemeanor depending on certain conditions. ${ }^{75}$ Basically, felony applies to acts involving sexual engagement with persons under 18 years old, and attracts 10 to 30 years imprisonment and US $\$ 2,200$ to US $\$ 11,000$ penalty. Misdemeanor deals with enslavement for lucrative purposes, including forcing one's slave to work or engage in prostitution. Such acts attracts five to 10 years imprisonment and US $\$ 1,000$ to US $\$ 2,000$ penalty. This categorisation seems to have allowed enforcement officers

$75 \quad$ See Loi $\mathrm{N}^{\circ} 2003-025$ du 13 juin 2003 modifiant la loi $\mathrm{N}^{\circ}$ 61-27 du 15 juillet 1961, portant institution du Code Pénal, Journal Officiel spécial N 4 du 7 avril 2004, arts 207(1), 207(2), and 207(3). 
to qualify acts of felony mostly under misdemeanor and, consequently, impose more lenient penalties in cases of infringement.

On the other hand, Nigerien law did not proscribe other forms of trafficking in persons until 2010. Because non-criminalisation of human trafficking provided a window for slavery practices to escape the scrutiny of the 2003 amendment of the Penal Code, a law on trafficking was welcomed. The December $2010 \mathrm{Law}^{76}$ is largely inspired by the UN 2000 Convention, ${ }^{77}$ which Niger ratified in 2004. According to that law, trafficking is punishable with five to ten years imprisonment and USD $\$ 1,000$ to $\$ 10,000$ penalty. Severe sentences and penalties apply to aggravated circumstances, such as trafficking in children. However, the pace at which Niger acts in the fight against slavery and human trafficking is slow. It was only on 21 March 2012 that the Government discussed a draft decree to implement the anti-trafficking law and create a National Agency to oversee its enforcement as well as compensation funds for victims. ${ }^{78}$ Despite these efforts, and considering the trans-border nature of human trafficking in West Africa, further action is needed to bolster domestic legislation and policy implementation. Regional legislation and multilateral cooperation under the auspices of ECOWAS should be considered. ${ }^{79}$

Niger's numerous reservations to CEDAW support recourse to the idea that they should be a more effective use of regulation making powers of the executive to foster implementation of existing laws. This is more so as the CEDAW Committee has declared many of Niger's reservations to Convention as contrary to its object and purpose. ${ }^{80}$ The Committee equally singled out the need to address legal and regulatory provisions that discriminate against women in Niger. These are, to cite but a few, the application of three different sources of law, a patriarchal ideology with firmly entrenched gender stereotypes, and deep-rooted culture, customs and traditions that prevent the enjoyment of women's rights. ${ }^{81}$

In the light of the foregoing, tackling slavery practices in the specific environment of Niger requires more than just adding anti-slavery provisions to the penal code. Further regulation and legal harmonisation are apparently wanting. In the presence of a penal code that criminalises slavery practices, it falls within the duties of the executive to take

$\overline{76}$ See Ordonnance $N^{\circ} 2010-86$ du 16 décembre 2010 relative à la lutte contre la traite des personnes.

77 Protocol to Prevent, Suppress and Punish Trafficking in Persons, Especially Women and Children, supplementing the United Nations Convention against Transnational Organized Crime (adopted 15 November 2000, entered into force 25 December 2003) 2225 UNTS 209.

78 See Relevé of the Cabinet's meeting, para 4(3) in Info Niger, 'Au Conseil des ministres: le gouvernement adopte plusieurs projets de textes’ <http://217.19.227.146.static.hosted. by.combell. com/presse/societe/au-conseil-des-ministres-le-gouvernement-adopte-plusieurs-projets-detextes/> accessed 6 July 2012.

79 The relevance of cooperation is illustrated by the inter-country investigation organised by Niger with Mali and Togo that led in 2009 to the arrest of traffickers. See US Department of State, '2009 Niger trafique des personnes' <http://photos.state.gov/libraries/niger/885/french/report_006. pdf> accessed 6 July 2012.

80 See UN Committee for the Elimination of All Forms of Discrimination Against Women, 'Concluding Comments: Niger' (11 June 2007) UN Doc CEDAW/C/NER/CO/2, para 9. Ibid paras 15-17. 
complementary legal measures such as those mentioned above. In a presidential system of government like the one in Niger, legislative and other exceptional powers afforded to the President should not be considered as a personal privilege. They should rather be used to address issues that are of prime importance to the country and society. The President and Government of Niger, therefore, have a duty to utilise their law and regulation making powers to ensure that anti-slavery provisions in the penal code translate into reality. At the time of writing, these authorities have yet to fulfil the immense promises brought by the ECCJ's Koraou judgment. The Government and domestic courts were the two addressees of the ECCJ's condemnation in the Koraou judgment, and it seems that the domestic courts have been better followers of the ECCJ.

\subsection{IMPACT OF THE KORAOU JUDGMENT ON NIGERIEN COURTS}

A previous section of this paper suggested that relations between international and domestic courts proceed from either legal requirements, for instance preliminary rulings mechanisms, or jurisprudential influence depending on the authority of the issuing body and the openness of the receiving one. This section first discusses any obligation for domestic courts to subject themselves to the ECCJ's jurisprudence before examining its actual and potential impact on Nigerien courts.

\subsubsection{The ECOWAS Court and domestic courts: Jurisdictional relationship or co-operation?}

Examining the relationship between the ECCJ and domestic courts implies investigating the nature of such a relationship. More specifically, any question raised will eventually seek to clarify whether the relationship, if established, is one that shapes cooperation and collaboration; as well as whether established relationships are potentially conducive to influence in both directions.

Reading from the law, two types of relationships are possible between the ECCJ and domestic courts. ${ }^{82}$ The first possible channel of legal and jurisdictional relationship is the mechanism of preliminary ruling introduced by the 2005 Community Court Protocol. Article 10(f) of the Protocol provides that 'where in any action before a court of a Member State, an issue arises as to the interpretation of a provision of the Treaty,

82 In reference to the rules that apply in the two other main regional integration regimes in the region - UEMOA and OHADA - these relations are known as 'jurisdictional authority'; the regional court's authority ensues from an horizontal relationship that is exerted through the preliminary ruling mechanism and a vertical relationship exerted through the binding nature of the community court's decisions on domestic courts, through the State. On the relationship between UEMOA and OHADA Courts and the domestic courts of their Member States, see A Zinzindohoué 'Autorité juridictionnelle des cours internationales à l'égard des cours nationales: le cas de la Cour de justice de l'UEMOA' in AHJUCAF (ed) Internationalisation du Droit, Internationalisation de la Justice Actes du $3^{\mathrm{e}}$ Congrès de l'AHJUCAF (21-23 juin 2010) 22-28. 
or the other Protocols or Regulations, the national court may on its own or at the request of any of the parties to the action refer the issue to the Court for interpretation'.

Sticking to the letter of the provision, while a window is open for relationship, one may argue that, prima facie, such relationship does not seem to have the potential of yielding any influence of the Community Court on domestic courts. A first reason for this is that the preliminary ruling mechanism refers only to the interpretation of the ECOWAS Treaty and other laws enacted in the framework of the Community and that can be termed as 'community law' - also hereafter referred to as ECOWAS 'original law'. ${ }^{83}$ It follows that, strictly speaking, the mechanism does not apply to the interpretation of provisions of the African Charter, which mainly forms the normative basis of the ECCJ's human rights jurisprudence.

Another reason, certainly the most important, is the fact that the preliminary ruling mechanism provided under article 10 (f) is only optional. Domestic courts may, therefore, choose not to refer interpretation of ECOWAS law to the ECCJ. The use of this opportunity to strengthen relationships that will give rise to potential influence therefore appears far-fetched. The relationship will also eventually depend mainly on the 'spirit of cooperation' of domestic courts. As a matter of fact, at the time of writing, not a single preliminary ruling request has been filed before the ECCJ in ten years of operation. ${ }^{84}$

Despite these limitations, the preliminary ruling has a strong potential to create indirect influence. A first advantage is that the mechanism will help regulate the division of labour when domestic courts or their litigants decide to seize the ECCJ. ${ }^{85}$ In other words, the Community Court will interpret and domestic courts will apply

83 Original ECOWAS law includes the Revised Treaty, Protocols, Regulations and any other treaties adopted by Member States under the aegis of the Community, as opposed to what could be called 'imported' or 'borrowed' law, among which is the African Charter on Human and Peoples' Rights, which is an African Union human rights instrument, ratified by all ECOWAS Member States, included as a principle of the Community by the 1993 reforms and added to its 2002 Protocol on Democracy and Good Governance as a principle common to the constitutions of all Member States.

84 The situation may be attributed mainly to the limited economic interaction among ECOWAS countries, which in turn explains the poverty of related litigation; and by human rights matters overwhelming the ECCJ's docket following the 2005 reform. See A Sall, La justice de l'intégration: réflexions sur les institutions judiciaires de la CEDEAO et de l'UEMOA (CREDILA 2011) 36. The situation is no better in other sub-regional courts in Africa. For instance, in ten years of operation, the Court of Justice of the East African Community has received one referral from the High Court of Kenya. See JE Ruhangisa, 'The East African Court of Justice: Ten Years of Operation, Achievements and Challenges' Paper presented during the sensitisation workshop on the role of the EACJ in the EAC integration Kampala (on file with author) (1-2 November 2011) 22-23. Conversely, arguably due to the fact that individuals and legal persons can initiate suits against States for non-compliance with original community law, such cases have made up the majority of matters adjudicated in the East African Court of Justice and SADC Tribunal. However, the lack of an express jurisdiction to hear individual human rights complaints certainly explains such a trend.

85 See HN Donli, 'The Law, Practice and Procedure of the Community Court of Justice: Meaning and Implication' Paper presented at the Workshop on Law Practice and Procedure of the Community Court of Justice - ECOWAS, organised by the West African Human Rights Forum (Bamako, Mali, 7-9 December 2006) 10. 
community law. More importantly, despite the impression that the relationship is horizontal and therefore puts the two categories of courts on the same level, domestic courts cannot set aside the interpretation given by the Community Court in its preliminary rulings. ${ }^{86}$ Harmonisation, and indeed regional integration, comes at that price. Influence thus becomes unavoidable.

In addition to the indirect, and currently dormant, potential of the preliminary ruling mechanism, there is a second possible channel for influence between the ECCJ and domestic courts. Indeed, the binding nature of ECCJ's decisions extends to domestic courts as state organs. The 'direct enforceability' and precedence of ECCJ's decisions should, therefore, apply to domestic decisions ${ }^{87}$ It follows that, as for any other judgment of the Community Court, its human rights judgments enjoy a certain authority over the pronouncement of domestic courts. Whether domestic courts concede such authority and actually respect it is a different issue.

In that respect, one may argue that the legal basis of the ECCJ's human rights jurisdiction does not form part of ECOWAS 'original' law per se, i.e. legislation enacted under the auspices of the Community. The judicial part of the problem and, indirectly, its legal part have been resolved by the Community Court right from its first human rights pronouncement. In Ugokwe v. Nigeria, though it eventually threw out the case for lack of jurisdiction, the ECCJ asserted that:

The distinctive feature of the Community legal order of ECOWAS is that it sets forth a judicial monism of first and last resort in Community law; and if the obligation to implement the decision of the Community Court lies with the national courts of Member States, the kind of relationship existing between the Community Court and these national courts of Member States is not of vertical nature between the Community and Member States, but demands an integrated Community legal order. The ECOWAS Court is not a Court of Appeal or a Court of Cassation. ${ }^{88}$

Some provisions of Community law seem to support the position of the Court. To begin with, the African Charter, which forms the legal basis of the human rights jurisdiction of the ECCJ, is part of the municipal law of Member States either through ratification

86 Ibid. As the author, then President of the ECOWAS Court, stated, the 'ECCJ's role here is to give preliminary ruling as to the interpretation or validity of the Treaty provision or community Act, while the National Courts shall apply the ruling to the facts of the case. In other words, the Court's role is to interpret, while the National Court's role is to apply'. The permissive language 'may' used in the ECOWAS Court Protocol may be misleading; although the same wording is used in the relevant laws, the municipal judge may not depart from the UEMOA and OHADA Courts' rulings on validation or interpretation. The labour is shared, interpretation being left to the supranational court while domestic courts will only apply the ruling originating from 'above'.

87 The same rules apply to decisions originating from the UEMOA Court of Justice and the OHADA Community Court of Justice and Arbitration, which have jurisdiction over several ECOWAS Member States. See Zinzindohoué (n 82). 
and incorporation or because the Charter has been incorporated, directly or indirectly through many ECOWAS instruments. For instance, the 1993 ECOWAS Revised Treaty adopts the African Charter human rights as community principles upon which the Court has established its jurisdiction in the Ugokwe case. In addition, the ECOWAS Protocol on Democracy and Good Governance reinforces the adoption of the African Charter human rights as a 'common' body of law, which ECOWAS Member States are obliged to the Community to respect. The principle thus adopted by ECOWAS is known as convergence constitutionnelle. ${ }^{89}$ The argument can be made that since the Charter provisions have been made part of ECOWAS law through these instruments, ratification of the latter make those provisions directly applicable in Member States.

Whether original ECOWAS law or the African Charter, the overlapping jurisdiction of the ECCJ with national courts has the potential to give rise to conflicting interpretations. It goes without saying that to enable harmonisation, the 'integrated Community legal order', for which the ECCJ advocates, will need to be tempered by a necessary reception or acceptance ${ }^{90}$ of the Community Court jurisprudence by domestic courts. To avoid clashes that are detrimental to its authority, the ECCJ will, therefore, have to use caution in adjudicating cases that have been examined by domestic courts before making their way to Abuja. Case law and compliance analysis suggests that the Court has succeeded so far. ${ }^{91}$

The problem with the 'judicial monism' and the 'integrated Community legal order', which the ECCJ strongly calls for, is its 'ostrich' approach to legal harmonisation and regional integration. In fact, as the situation stands, domestic norms and court pronouncements inconsistent with ECCJ case law can subsist because the position of the Court is confusing. Actually, the Court may be said to be embracing caution to avoid adversity from States, especially when it decides not to make findings that risk contradicting the precedent of domestic courts. The current trend consists of finding in its arguments and motivation that domestic law and practice fall short of international standards but failing to draw the relevant consequences and making corresponding orders in the operative part of the judgments. ${ }^{92}$ However, objectively,

$89 \quad$ See art 1(h) of the ECOWAS Protocol on Democracy and Good Governance, which provides that 'The following shall be declared as constitutional principles shared by all Member States ... The rights set out in the African Charter on Human and People's Rights and other international instruments shall be guaranteed in each of the ECOWAS Member States'.

90 Due to their binding nature.

91 However, as discussed elsewhere, the Court should not equate 'pro-cooperation' caution with excessive self-restraint that may also lead to a loss of confidence and authority. See H Adjolohoun (n 40).

92 See Ameganvi Isabelle Manavi v Togo (2011) ECW/CCJ/JUD/09/11. The case involved nine Members of the Parliament of Togo who were removed through an unfair domestic process endorsed by the Bureau of the Parliament and the Constitutional Court. After finding a violation of the right to a fair hearing in the initial judgment, the ECOWAS Court, however, did not draw the consequence of such a finding on the previous decisions of the Constitutional Court, and avoided ordering that the domestic process be conducted anew. This silence led the complainants to request for a review seeking to clarify what the Court meant by 'remedy' the violation. The Court then held that it cannot make a pronouncement on the reinstatement of the complainants. 
the Community Court cannot be blamed for adopting prudence in sending judicial signals to domestic courts by sticking to its express prerogatives under the law. The ECCJ cannot grant itself the authority to directly reverse national courts' decisions while it has no such prerogatives under the law.

Having said that, the status of the ECCJ's decisions in the domestic order suggests an implied jurisdictional superiority deriving from supra-nationality and jurisprudential authority. One important part of the relevant provision is that "only the Community Court may suspend a writ of execution issued in enforcement of its decisions". ${ }^{93}$ As a consequence of the fore-going, it will be difficult to sustain that there is no potential for influence from the ECCJ through the superiority ensuing from the binding nature of its decisions on states, including their courts. As explained earlier, even preliminary rulings are binding on domestic courts. ${ }^{94}$ The refusal of domestic courts to recognise that the ECCJ's judgments are enforceable notwithstanding contrary domestic decisions may as well attract non-compliance sanctions on the defendant states. ${ }^{95}$ More importantly, such superiority is indispensable to ensure consistent interpretation of African human rights law and the same applies to the need for a constant dialogue between the African Union human rights bodies, the ECCJ and domestic courts. ${ }^{96}$ Generally, a different approach would prejudice the realisation of ECOWAS objectives, among which is legal harmonisation.

The fact that the ECCJ has made initial use of some relevant provisions of its Protocols should facilitate jurisprudential cooperation on the part of domestic courts. For instance, in the early years of its operation, the Community Court has taken the lead in that line by organising frequent visits to Member States during which judges and senior staff of the ECCJ interacted with state organs, namely domestic courts. Of note, the ECCJ has also used the possibility provided by the 1991 Court Protocol to hold deliberating sessions in the premises of the highest court of the defendant state. ${ }^{97}$ A factor that also militates for cooperation and influence is the reform introduced

93 Article 15 of the ECOWAS Treaty provides that the ECCJ's judgments are binding on Member States, which include domestic courts. Article 24 of the 2005 ECCJ Protocol confirms that judgments of the Court are binding and further provides that execution shall be in the form of a writ of execution issued by the Registry of the Community Court. The only condition for reception and enforcement is that the national authority designated by Member States will verify that the judgment is from the ECCJ.

94 See Donli (n 85) 10. According to Justice Donli, 'where the Court rules on a preliminary reference it is binding on the National Court which referred the question for consideration. If the same issue arises again in a latter case, then under the doctrine of acte clair, there is no need to make a further reference and if the National court is unhappy with the previous ruling, it can make an additional reference, even if the matter is acte clair'. See Costa $v$ ENEL App no 6/64 (ECtHR, 15 July 1964).

95 See ECOWAS Revised Treaty, art 77.

96 See Viljoen (n 9) 451-456; and ES Nwauche 'Enforcing ECOWAS Law in West African National Courts' (2011) 55 Journal of African Law 181-182.

97 For instance, in the Koraou Slavery case, the ECCJ held it sessions at the Supreme Court of Niger; the same was done at the Supreme Court of Benin in October 2011, where the West African Court held its sessions in cases involving Benin but also the Parliamentarians' case involving neighbouring Togo. The ECCJ has also held a session at the Supreme Court of Mali. 
by the 2006 Court Protocol that established the Judicial Council of the Community. Among others, the Council is established to oversee the process for recruiting professional judges from domestic courts who will serve on the ECOWAS Court. As they are only on a temporary posting for the duration of their term in the regional court, the judges will return to the judiciary in Members States with new experiences on international procedure and adjudication, ECOWAS law and jurisprudence. The return effect will certainly enhance cooperation and produce influence.

All in all, there is room for the ECCJ to influence domestic courts through judicial cooperation and legal implications on the one hand. Influence is possible through the mechanism of referral. On the other hand, the binding nature of the ECCJ's decisions on States applies to domestic courts and creates opportunities for influence. However, the relevance of these two channels is subject to the readiness of domestic courts to cooperate. The reason is that there is no legal hierarchical relationship between the ECCJ and domestic courts. The Court itself has conceded that the relationship is not vertical, thus not one of superiority. Having said that, the promotional activities of the Court have the potential to enhance cooperation and facilitate influence. It also appears that while the ECOWAS regime adopts non-exhaustion of local remedies and a 'judicial monism', the fact that several cases decided by the Community Court were previously examined by domestic courts has influenced the relationship. It seems that, although parties and issues were 're-adapted' to international proceedings, domestic courts' decisions largely formed most of the arguments discussed in the ECCJ's judgments, thus allowing for indirect scrutiny. The actual picture is more of an inevitable influence. The impact of the ECCJ's Koraou judgment on Nigerien courts is probably the most visible so far.

\subsubsection{How and why the Koraou judgment impacted on Nigerien courts}

It is important at this point to recall that Niger's responsibility in the Koraou case was triggered mainly by the failure of domestic courts to deal with her complaints timely and effectively. ${ }^{98}$ Instead of protecting the complainant through an interdict order and charging the accused, the criminal court charged the complainant with bigamy. The primary responsibility of domestic courts in proceedings that preceded the hearing of the case in the ECCJ demands a corresponding assessment of the attitude of municipal judges in the post-Koraou era.

In view of the wide publicity given to the case, its hearing in Niger and the speedy compliance on the part of the state, one would have expected the ECCJ's Slavery judgment to impact on the work of domestic Nigerien courts in several ways. For instance, the Community Court judgment had the obvious potential of leading domestic courts to drop all charges pending against the complainant. One would have additionally expected domestic judges to become more sensitive to slavery related

$\overline{98 \quad \text { See Badet (n 22) }} 158$. 
matters by expediting such proceedings and adopting a more appropriate application of the Nigerien anti-slavery law. Particularly, domestic courts should have taken a more ECCJ-oriented approach to post-Koraou domestic slavery proceedings.

Even if remaining charges pending against Koraou in domestic courts were eventually dropped, the connection with the ECCJ's judgment is difficult to ascertain. In fact, at the time the ECCJ was seized of the matter charges were already dropped in the main proceedings. ${ }^{99}$ The challenge for domestic courts, therefore, laid in demonstrating openness vis-à-vis the ECCJ's pronouncement in dealing effectively with subsequent slavery cases.

As an illustration of the domestic courts' openness to the ECCJ's Slavery jurisprudence, one could cite a case that has a direct connection with the Koraou case. On 31 March 2009, the Correctional Tribunal of Konni charged Koraou's master Naroua with slavery. The court sentenced Naroua to one year imprisonment and a CFA 500,000 (USD\$1,000) penalty. Prior to the Government initiating the circulaire referred to earlier, judges are believed to have changed their approach to slavery cases on the grounds of the ECCJ's judgment. They were said to have become more sensitive to new cases to which they reacted promptly. ${ }^{100}$ In fact, it must be pointed out that domestic courts had demonstrated the willingness to make anti-slavery pronouncements in implementation of the 2003 law prior to the ECCJ judgment in October 2008. One such instance is with no doubt the August 2008 landmark case of Prosecutor $v$. Tafane Abouzeidi, ${ }^{101}$ in which the Abalak Tribunal charged the defendant with slavery, sentencing him to one year suspended imprisonment and a CFA 100,000 (USD\$200) penalty. The court further granted CFA 2,5 million (USD\$5,000) in damages to the two victims.

Even if there are few cases similar to the Abouzeidi judgment and the application of anti-slavery provisions remains limited, subsequent developments of the case in the domestic courts after the ECCJ's judgment seem to suggest a direct impact. Indeed, the Appeal Court of Niamey ${ }^{102}$ reversed the Abouzeidi judgment in early 2009 after the ECCJ had passed judgment. The Appeal Court found that the slavery offense was not properly constituted while the defendant had admitted exercising property attributes and perpetrating degrading treatment on the victims. Having won the Koraou Slavery case in the ECCJ, the local anti-slavery NGO Timidria was well aware of the benefit it could draw from the wide popularisation of the case. The NGO challenged the Appeal Court's decision before the Court d'Etat, the highest court in Niger under the military rule between February 2010 and March 2011. The Court d'Etat reversed the Appeal

\footnotetext{
99 Duffy writes that while the case was still pending before the ECOWAS Court, the criminal case against Koraou was lifted. See Duffy (n 26) 66. The complainant won four of the seven cases pending before the courts while the ECCJ was still busy hearing the matter. See also interview with Hamani (n 27). Interview with Hamani (n 27).

101 See Prosecutor v Tafane Abouzeidi (2008) Judgment No 45, Tribunal of Abalak, Niger.

102 See Tafane Abouzeidi v Prosecutor and Others (2009) Judgment No 11, Appeal Court of Niamey, Niger.
} 
Court's decision, confirming that slavery was constituted. ${ }^{103}$ The decision of the then Niger's court of cassation was no stranger to the fact that the state had just - a first in its history - paid USD\$20,000 in damages to an individual for slavery. Moreover, the country was under close regional and international scrutiny and ECOWAS had maintained political pressure to ensure that the military junta behaved.

Actually, the social and religious perception of slavery in Niger imposes a more critical and dialectical approach to the potential influence of the ECCJ's Slavery judgment on domestic judges. Like ordinary citizens, Nigerien judges are subjected to the pro-slavery social and religious environment of Niger. For instance, the judge who heard the first domestic criminal case of the Koraou judicial saga is said to be of a 'traditional obedience', which could explain why he made such a decision without serious legal reasoning. ${ }^{104}$ Moreover, investigations revealed that due to the fact that slavery widely remains a taboo in the country, awareness is still weak and judges have released slavery suspects in some instances without proper investigation. ${ }^{105}$

As pointed out earlier, the Government circulaire for domestic courts to expedite slavery related matters was not enforced. A proper enforcement could have mitigated the bias problem. While they are said to have definitely been impacted by the ECCJ's Koraou judgment, judges' bias is exposed through the way in which they perceive slavery. Being from a certain tribe or sitting as traditional chiefs, some judges hearing slavery cases barely deny the very existence of the plague and do not consider related complaints as 'extraordinary' matters. The case of Adamou Aboubacar et al v. Mani Algoumarat already illustrated this position adopted by domestic courts in the pre-ECCJ's Koraou judgment era. ${ }^{106}$ Even in the post-Koraou era, judges do not approach slavery as a 'violent' or outrageous crime ${ }^{107}$ because, as defendant masters contend in frontline instances, slaves now receive food; ${ }^{108}$ they are remunerated and the terminology for naming them has even changed to 'domestic workers'. ${ }^{109}$ This approach to such a heinous crime as slavery shows a complete disconnect with the rejection of slavery in international jurisprudence since the Nuremberg trials. Indeed, there can be no 'good slavery'. 110

103 See Assibit Wannagara and Others $v$ Prosecutor and Tafane Abouzeidi (2011) Judgment No 11-119/P, Cour d'Etat, Niger.

104 See interview with Ibrahim Habibou (n 70).

105 Ibid.

106 See Adamou Aboubacar et al v Mani Algoumarat (2004) Customary Law Judgment No 15, Délégation judiciaire of Bouza, Niger. In this case concerned with an alleged land expropriation, the claims of the complainants that the expropriation was based on their status as slaves were rejected by the court as 'sensational' which the Judicial Delegation (the domestic court) said it decided to 'distance itself from'.

107 In application of the 2003 anti-slavery law, domestic courts have never qualified slavery as a felony but only a misdemeanor. See interview with Advocate Chaibou, counsel for the complainants in the Koraou, Aboubacar and Abouzeidi cases (n 27).

108 See Abouzeidi judgment.

109 See interview with Advocate Chaibou (n 27).

$110 \quad$ See Badet (n 22) 158. 
Stakeholders agree that the main problem is not with the law but with the attitude and perception on the part of judges and other state officials. However, there is also a need to ensure that both judges and investigating officers acquaint themselves with the law. Its application is still marred with difficulties of properly categorising slavery cases involving associated offenses such as expropriation and assault. In several instances, the problem lies with the way in which the charges were formulated. ${ }^{111}$ Among other consequences, this has resulted in the word slavery not being mentioned even once in some domestic slavery cases. ${ }^{112}$

\subsection{HAS THE ECCJ BEEN INFLUENCED BY NIGERIEN COURTS?}

Writers have discussed the influence of domestic courts on their international counterparts. Case law has illustrated how complex international law questions may be addressed by referring to domestic jurisprudence. ${ }^{113}$ Examples abound of international courts assessing cases presented to them through the knowledge of national judges, counsel and other litigants in their submissions and pleadings. ${ }^{114}$ Compliance has been facilitated by reliance on domestic courts' findings. ${ }^{115}$ Conversely, international courts have suffered criticism for their lack of ability to remain in touch with realities on the ground while locally informed proceedings have proved to maximise the impact of international adjudication. ${ }^{116}$ The ECCJ's Koraou judgment illustrates the overall conclusion that international courts never operate in a vacuum but mostly on the basis of domestic applications of the law. ${ }^{117}$

Despite the adoption by the ECOWAS human rights regime of non-exhaustion of local remedies, the majority of human rights cases adjudicated by the Community Court were previously heard by domestic courts at some stage. As a consequence, not only the facts but also the legal arguments presented at the domestic and international levels were nearly the same. In fact, the complainants did not differ either, and it became unrealistic to expect that the ECCJ could avoid the influence of the deliberations and decisions made in domestic courts. Actually, the Community

\footnotetext{
111 Ibid.

112 Ibid.

113 See for instance Canivet (n 32). The author argues that international bodies have mainly been established on the model of domestic courts, and the trend of domestic judicial mechanisms taking from international ones is more of a recent occurrence. International courts also recruit judges from domestic systems. The interpretation by the ICJ of article 38 of its Statute as prescribing reference to both international and national decisions is in support of bottom-up influence. See for instance the Arrest Warrant of 11 April 2000 Case (Democratic Republic of Congo v Belgium) (Judgment) [2002] ICJ Rep 3, Prosecutor v Tadić (Judgment) Case No. IT-94-1-T ICTY Trial Chamber (7 May 1997) and Prosecutor v Furundžija (Trial Judgment) Case No. IT-95-17/1-T ICTY (10 December 1998).

114 See Garlicki (n 33) 517.

115 See Cavallaro and Brewer (n 57) 794.

116 Ibid 818

117 Ibid 819; Tzanopoulos (n 39) 15; and Garlicki (n 33) 512.
} 
Court had to bear the influence of the domestic socio-political dynamics brought by the cases. In the process, the ECCJ was influenced by domestic courts at least from two perspectives. First, through prior discussions of the issues involved, domestic courts made the facts easier for the ECCJ to comprehend, namely from the social and political context of the specific country. Second - ECOWAS member states being of both civil and common law traditions - the need for the Community Court to benefit from the legal argumentation already built up during domestic proceedings was satisfied and increased the pace of the ECCJ's work. ${ }^{118}$

In the Slavery case, the findings of the Community Court were in line with some previous or concomitant decisions of domestic courts to drop charges against the complaint in the majority of the proceedings. In addition, the ECCJ relied heavily on the domestic proceedings in reaching its own decision. There is equally evidence that the ECCJ was influenced by matters being examined by domestic organs at some stage. ${ }^{119}$ There could have been greater bottom-up influence if the ECCJ had adjudicated more slavery cases with express reference to domestic courts judgments. Of note, the ECCJ has not received any slavery related case since the Koraou judgment, despite continuing slavery practices in Niger and neighbouring countries. This could mean either that Nigerien courts are dealing with domestic cases effectively, which does not appear to be the case, or the absence of cases from other countries is an evidence of the ECCJ's impact. The absence of slavery cases in the ECCJ in the postKoraou era could also mean that there was no impact at all. However that hypothesis can be ruled out by the evidence of influence discussed earlier. ${ }^{120}$

In any case, there are advantages to influence; mainly that it is likely to benefit the necessary cooperation between the ECCJ and its domestic counterparts. The influence or orientation of domestic courts will prevent the Community Court from making pronouncements that set confrontational relationships, with the potential of jeopardising the authority of the ECCJ. On the contrary, as a result of its current adjudication policy, the ECCJ has been able to strike a balance between individual rights and state socio-political contingencies. The major consequence is that decisions of the ECCJ have been widely accepted by respondent states and political organs of ECOWAS so far. Such acceptance is central to the development of the authority of the Community Court in the region particularly because states and their organs have traditionally been reluctant regarding the non-exhaustion of local remedies. Using domestic courts as its 'eyes and ears' in ECOWAS countries will

118 As discussed elsewhere, this might explain why the Court is currently one of the fastest international bodies to adjudicate cases. It takes the Court a rough average of 15 months to complete one case. It has previously completed a case within four months and the lengthiest proceedings lasted three years. See Adjolohoun (n 40).

119 See Adjolohoun ibid.

120 See previous sections of this article discussing the influence of the Koraou Slavery judgment on the executive, judiciary and legislature. 
function as an indirect exhaustion of local remedies and legitimise ECCJ's decisions nationally. ${ }^{121}$

In essence, the ECCJ's decisions have been influenced by domestic courts in the sense that whenever the matter was previously dealt with domestically, the Community Court has declined jurisdiction unless it was not properly adjudicated at the national level. Influence can also be derived from the fact that the ECCJ has always avoided reversing judgments of domestic courts in an express manner, and therefore has upheld such decisions. Finally, legal argumentation in the judgments of the Community Court have been informed either by prior proceedings in domestic courts or by submissions of counsel, some of them having participated in domestic proceedings.

\section{4. 'SPILL OVER' INFLUENCE OF THE KORAOU JUDGMENT ON OTHER ECOWAS COUNTRIES}

'Spill over' or 'irradiating' effects require time to develop. Such effects are not perceptible on a large scale yet as the ECOWAS Court has only exercised its human rights mandate for less than a decade at the time of writing. However, there is evidence of irradiating effects that embed the potential of wider effects over time as the system develops. The effects discussed are therefore both actual and potential.

The most visible impact of the Koraou judgment has been on Mali, another country in the region where the ignominy of slavery is current. Although slavery is said to have officially ended at independence in 1960, thousands of individuals are still enslaved in Mali. ${ }^{122}$ Even if Mali has yet to enact a law criminalising slavery, the country's Constitution guarantees equal protection under the law that can in many respects be interpreted as prohibiting slavery. A member of a wide antislavery regional network said member NGOs in Mali have used the ECCJ's Koraou pronouncement to push the Malian Government to tackle the phenomenon more seriously. ${ }^{123}$ In 2011, nearly four years after the ECCJ's Koraou judgment, Mali's Ministry of Justice supported the establishment of a law clinic within the local antislavery organisation Temedt with the support of the American Bar Association. The clinic works to provide free legal services to enslaved persons seeking their freedom and trains lawyers, police, prosecutors and judges on handling slavery cases. Its mandate extends to providing psychological assistance and vocational training to the victims visiting the clinic as well as outreach awareness campaign. An on-going

\footnotetext{
121 See Adjolohoun (n 40).

122 See Integrated Regional Information Network (IRIN), 'Thousands Still Live in Slavery in Northern Mali' (14 July 2008). <http://worldpress.org/Africa/3198.cfm> accessed 26 April 2012.

123 See interview with Weila (n 73).
} 
process includes the finalisation of a draft law criminalising slavery and advocacy for its adoption. ${ }^{124}$

\section{IMPACT OF THE KORAOU JUDGMENT BEYOND ECOWAS}

The Koraou judgment has impacted on human rights systems and mechanisms beyond ECOWAS. The closer the countries, the faster the impact. Despite its geographic proximity to ECOWAS, Mauritania is not a member of the Community. In any case, slavery figures are much more alarming in Mauritania than in Niger and Mali. Antislavery organisations estimate that nearly a fifth of Mauritania's 3.1 million people were slaves as of $2009 .{ }^{125}$ The fact that Mauritania criminalised the practice in 2007,126 a year before the ECCJ delivered judgment in the Koraou case, could have bolstered implementation. Mauritanian authorities seem to have neglected the popularisation of the 2007 Law, under which there have not been any convictions and dozens of slavery suits were dismissed in 2008. ${ }^{127}$ All anti-slavery organisations in the region are members of a regional anti-slavery network, however stakeholders ${ }^{128}$ believe that the case of Niger has advanced the same cause in Mauritania. Since the new law was passed, Mauritanian anti-slavery lawyers have been involved in at least seven reported slavery cases that have resulted in the release of more than a dozen people from their masters. However, despite the fact that all of these cases were reported to the authorities, there has not been a single prosecution or any significant investigation into individuals responsible for crimes of slavery. Anti-slavery activists have also been imprisoned for staging demonstrations pointing to the challenges of implementing the law. ${ }^{129}$

ECCJ's Koraou judgment has also impacted on the work of international mechanisms. The ECCJ's decision greatly contributed to putting Niger in the spotlight during the United Nations Human Rights Council's session examining the country's report under the Universal Periodic Review in 2011. ${ }^{130}$ The number

124 See American Bar Association, 'Anti-Slavery Program Launched in Mali' (June 2011) <www. americanbar.org/advocacy/rule_of_law/where_we_work/africa/mali/news/news_mali_anti_ slavery_program_launched_0611.html> accessed 26 April 2012.

125 See IRIN, 'Mauritania: Activists' trial puts spotlight on anti-slavery law' <www.irinnews.org/ Report/91528/MAURITANIA-Activists-trial-puts-spotlight-on-anti-slavery-law $>\quad$ accessed 26 April 2012.

126 See Loi No 2007-048 of 8 August 2007.

127 See Z Nguimatsa Serge, 'Researching the Legal System and Laws of the Islamic Republic of Mauritania' (Globalex New-York University 2009).

128 See interview with Habibou (n 70).

129 See Anti-Slavery, 'SOS Esclaves' < www.antislavery.org/english/whatwedo/antislavery_ internationaltoday/award/2009awardwinner/default.aspx> accessed 26 April 2012.

130 See M Mubiala, 'L'application de la Charte africaine des droits de l'homme et des peuples par la Cour de justice de la CEDEAO’ Unpublished conference paper on file with author (2011) 6-7. 
of recommendations filed by third states with regard to slavery and related issues attest to the importance accorded by non-ECOWAS UN Member States to the ECCJ's judgment. Many of the recommendations speak directly to the major issues raised by the ECCJ in the Koraou judgment, including the lack of effective enforcement of the law and lack of effective domestic remedies; and undue delay in progressing slavery related cases. ${ }^{131}$

\section{CONCLUSION}

In addition to the specific remedies provided for by the execution of orders made in its judgments, the ECOWAS Court of Justice has impacted on numerous state systems, organs and other mechanisms within and beyond the borders of the Community. This paper investigated the impact of one of the ECCJ's landmark judgments at the domestic level, in other ECOWAS countries and beyond. Some major conclusions may be drawn from this analysis.

With regard to the impact on the executive, it appears that although the Nigerien Government has taken action to the effect of bolstering anti-slavery provisions in the 2003 penal code, executive intervention in the post-Koraou era proved slow. Specifically, the Government has yet to make implementing decrees and other regulatory acts required to ensure that judges, lawyers, and law enforcement personnel properly apply the law. With regard to legislative intervention, it remains necessary to not only enact complementary laws but more importantly to undertake harmonisation of the existing laws. In addition, the Government has to accelerate the process of enforcing the decree for implementation of the 2010 Law on human trafficking and the operation of the National Anti-Trafficking Agency.

Subject to cultural and, to some extent, religious bias, domestic courts have certainly proved to be the most productive channels for influence. Cases discussed above demonstrated both progressive and conservative trends among municipal judges. Social, cultural and religious realities in Niger suggest that a change in attitudes and perception about slavery will be catalytic to more effective judicial protection.

Active civil society and legal practitioners have also enhanced the ECCJ's influence. Stakeholders suggest catalytic effects of the Koraou decision following which 'approximately 30 women came forward to anti-slavery organisations seeking their own 'liberation". ${ }^{132}$ In the ECCJ's Koraou case, anti-slavery NGOs played a central role in collaboration with the lawyers. The role of Timidria, a frontline Nigerien anti-slavery organisation, with the notable support of Interights and Anti-Slavery International, proved to be instrumental to the impact of the case in Niger as well

\footnotetext{
131 Of a total of 81 recommendations filed at the session, 11 were addressed to Niger. See Mubiala ibid; and Global Observatory on Human Rights, 'Universal Periodic Review: Niger' <http://upr-epu. com/ENG/country.php?id=215> accessed 2 July 2012.

132 See Duffy (n 26) 66; and interviews with Habibou (n 70) and Advocate Chaibou (n 27).
} 
as in and beyond ECOWAS. These stakeholders intervened right from the decision to bring a suit to the Community Court through to the propaganda and publicity around the judgment.

A comprehensive investigation of the ECCJ's human rights jurisprudence reveals evidence of other domestic systems in the region being impacted by the work of the Court. A few cases are worth mentioning. For instance, following the ECCJ's judgments in the Manneh and Saidykhan cases referred to in the introduction to this article, the Gambia's Ministry of Justice implemented a capacity strengthening strategic document with the purported overall objective of 'rebranding the human rights image of the Gambia.' ${ }^{133}$ In late 2011 and early 2012, the Ministry also organised meetings and courses for law enforcement personnel on how to handle arrest and detention cases in line with internationally accepted standards. The ECCJ's influence was with no doubt reinforced by the fact that in 2008, the African Commission adopted a Resolution on the Gambia in which it called upon the Government to 'immediately and fully comply with the $5^{\text {th }}$ June 2008 judgement of the ECOWAS Community Court of Justice in respect of the release of Chief Ebrima Manneh from unlawful detention and pay the damages awarded by the Court'. ${ }^{134}$

After opposition parliamentarians were unseated in an unfair process, the ECCJ found violation and ordered monetary compensation in the case of Ameganvi v. Togo. ${ }^{135}$ Counsel for the complainants confirmed that in the months following the judgment, Togo's Minister of Justice instructed prosecuting authorities to act promptly in cases involving the state. ${ }^{136}$ The same is reported to have been done with the purpose of having domestic courts either release the suspects or complete proceedings to close the case to render new proceedings before the ECCJ moot. ${ }^{137}$

Similarly, the ECCJ's Habré judgment ${ }^{138}$ was brought to bear in the case of Belgium v. Senegal before the International Court of Justice. ${ }^{139}$ Although the ICJ reversed the ECCJ's Habré decision in its main substantive proposition - namely by making it

133 As reads the title of the main strategy document consulted by the author. The strategy and documents relating to various meetings made express reference to such a move being related to the ECCJ's judgments against the Gambia, which were mainly concerned with unlawful detention and illegal arrest. Although not served with copies of the relevant documents, letters and invitations, the author had access to them in the Directorate of Civil Litigation and International Law, Ministry of Justice, on 27 January 2012. Information was mainly obtained during an interview with Martins U Okoi, Director of Civil Litigation and International Law Department, Ministry of Justice (Banjul, 27 January 2012).

134 African Commission on Human and Peoples' Rights, 'Resolution 134 on the Human Rights Situation in the Republic of The Gambia' (24 November 2008) para 7.

135 Ameganvi Isabelle Manavi v Togo (2011) ECW/CCJ/JUD/09/11.

136 Interview with Advocate Zeus Ajavon, Counsel for the complainants in Ameganvi v Togo (Lome, 18 January 2012).

137 Ibid.

138 See Hissein Habré v Senegal (2010) ECW/CCJ/JUD/06/10.

139 See Questions relating to the obligation to prosecute or extradite (Belgium $v$ Senegal), (ICJ 20 July 2012). 
clear that Senegal has a duty to try or extradite Habré regardless of the time when the changes to the municipal occurred - the World Court made several references to the sub-regional Court's judgment. ${ }^{140}$ Substantive arguments in the ICJ judgment were based on argument and findings of the ECCJ. The impact of the Habré decision on the African Union is perceptible in the draft statute of the ad hoc tribunal proposed to try former president Habré. Indeed, article 1 of the draft proposed statute reads:

The purpose of this Statute is to establish an ad hoc international Court with international character for the prosecution of crimes committed in Chad during the period from 7 June 1982 to 1 December 1990, consistent with the decisions of the Assembly of the African Union (...), the judgment of the Court of Justice of ECOWAS (...) of 18 November 2010 and the United Nations Convention against Torture (...). ${ }^{141}$

In all, although it has not reached the level of the European irradiating model, there is evidence that the ECOWAS human rights regime has confirmed its potential to impact upon the domestic systems of defendant states as illustrated by the previous discussion of the Koraou case. The Community Court is sending signals to states in the region. Beyond the Community, the ECCJ's jurisprudence has begun to break through international mechanisms at both the African Union and United Nations' levels.

While it could be rightly argued that the ECCJ, and in fact the whole ECOWAS human rights regime, have been doing so good so far, implementing well-designed systems is not enough to ensure their effectiveness. ${ }^{142}$ The question, therefore, remains whether the ECOWAS human rights regime will be sustainable and how the Community Court will maintain its current trends and strengthen its credibility and authority in the region. The sustainability of the regime and of the Court's authority will no doubt depend to a large extent on how the fragile West African democracies develop and whether the rule of law engrains domestically. ${ }^{143}$ For this to happen,

140 In the ICJ case of Belgium $v$ Senegal, the defendant State argued that a decision that it should try Habré or extradite him would be at odds with its obligation to give effect to the ECOWAS Court's decision. However, the ICJ dismissed this argument and took the position that Senegal's duty to comply with CAT 'cannot be affected by the decision' of the ECOWAS Court. In any case, both Courts agreed that Habré must stand trial.

141 African Union, 'Draft Statute of the Ad Hoc International Court for Senegal', Addis Ababa (24 March 2011) Unpublished document as quoted by Mubiala (n 127) 9. See also Habré's Survivors' Fight for Justice, 'Progress Report of the Commission on the Hissene Habré Case - African Union' (July 2011) <www.facebook.com/notes/hiss\%C3\%A8ne-habr\%C3\%A9-justice-pour-les-victimesjustice-for-the-victims/progress-report-of-the-commission-on-the-hissene-Habré-case-africanunion/248799398468710> accessed 26 April 2012.

142 Alter suggests that the success of the European style courts will be real only under the two main conditions that the law applied by international courts is part of domestic law; and on the basis of dialogue between international and domestic courts. See Alter (n 47) 2.

143 Domestic government institutions that are committed to the rule of law and remain responsive to individual rights claims constitute a strong favourable precondition for effective supranational adjudication. See Keller and Stone Sweet (n 59) 333. 
ECOWAS' political organs and leading member states will have to take strong stances $^{144}$ against recalcitrant states that still make the system stammer. ${ }^{145}$ Only time $^{146}$ will tell whether ECOWAS member states have firmly decided to establish a human rights regime and if they have put in enough commitment to become an 'ECOWAS of rights'. If the answer is positive, the ECCJ may well become a promoter of human rights in Africa and beyond.

144 The weakness of the highest political authority and lack of state commitment to the integration process have been demonstrated to be the main hindrances of the European Court of Justice's ability to develop a 'regional' rule of law. See S Scheingold The Rule of Law in European Integration (Yale University Press 1965) as quoted in Alter (n 47) 5.

145 One such example is The Gambia, which has attempted to squash down the powers of the Court and has not complied with any of its judgments so far. In the European example, the entries of Russia, Poland, and Turkey have biased the outcome of litigation. See Keller and Stone Sweet (n 59); and LR Helfer, 'Redesigning the European Court of Human Rights: Embeddedness as a Deep Structural Principle of the European Human Rights Regime' (2008) 19 European Journal of International Law 125. In the Inter-American human rights system, countries like Peru and Venezuela have challenged the authority of the Inter-American Court. See Huneeus (n 45).

146 It took years for the European human rights system to become stronger and most of the current copies have faced similar situations as did the European model in 1950. See Alter (n 47) 5. 